\title{
Corpus-based Contrastive Study of Discursive Strategy of Construing Interpersonal Relations in English Language Academic Discourse
}

\author{
Larisa A. Kochetova and Inna V. Kononovab* \\ ${ }^{a}$ Volgograd State University \\ Volgograd, Russian Federation \\ ${ }^{b}$ St. Petersburg State University of Economics \\ St. Petersburg, Russian Federation
}

Received 07.10.2018, received in revised form 06.11.2018, accepted 20.11.2018

\begin{abstract}
Based on comparison of two corpora, BE2006 sub-corpus of learned (academic) prose and corpus of English language texts written by Russian scholars compiled by the authors, the article seeks to find out differences in interpersonal relations as they are construed in English-language L1 and English as a foreign language academic discourse. The study focuses on the use of the first person plural pronoun that being a genre convention admits exclusive and inclusive uses in their reference and represents culturally determined discursive strategy of construing communicative categories of solidarity, credibility, politeness, etc. Applying corpus methodology, the authors intend to reveal if there is a statistically significant difference in the frequencies of the first person plural pronoun, and what the use of the first person plural pronoun reveals about interpersonal relations within the compared data from academic discourses under study. Although the statistical tests did not indicate significant differences in the frequency of the pronoun in the contrasted corpora, qualitative analysis of the discourse data revealed that in the EFL corpus inclusive we is employed to persuade the addressee to share and accept the author's arguments whereas in the BE2006 corpus it is used to construe solidarity based on common background, shared beliefs and opinions.
\end{abstract}

Keywords: discourse, academic discourse, corpus, corpus methodology, English language, CQPWeb, AntConc.

The reported research was funded by Russian Foundation for Basic Research and the government of Volgograd region, grant № 18-412-340007.

Research area: philology.

Citation: Kochetova, L.A., Kononova, I.V. (2018 online). Corpus-based contrastive study of discursive strategy of construing interpersonal relations in English language academic discourse. J. Sib. Fed. Univ. Humanit. soc. sci., 2022 15(10), 1516-1523. DOI: 10.17516/1997-1370-0353

(C) Siberian Federal University. All rights reserved

* Corresponding author E-mail address: Kochetova@volsu.ru; kafedra_tlt@mail.ru 


\title{
Корпусное контрастивное исследование дискурсивной стратегии конструирования межличностной интеракции \\ в англоязычном академическом дискурсе
}

\author{
Л.А. Кочетова ${ }^{a}$ И.В. Кононоваб \\ ${ }^{a}$ Волгоградский государственный университет \\ Российская Федераичи, Волгоград \\ ${ }^{6}$ Санкт-Петербургский государственный экономический университет \\ Российская Федерация, Санкт-Петербург
}

\begin{abstract}
Аннотация. Основываясь на сравнительном анализе двух корпусов письменной академической речи, подкорпуса научной речи BE2006 и собственного корпуса научных статей российских авторов, написанных на английском языке, в статье выявляем различия в дискурсивной стратегии конструирования межличностной интеракции участников дискурса. В фокусе анализа находится частотность использования местоимения первого лица множественного числа, которое, будучи конвенцией жанра, в референциальном отношении обладает инклюзивным и эксклюзивным значениями и репрезентирует культурно обусловленные коммуникативные категории солидарности, достоверности, вежливости и т. д. Используя корпусную методологию, авторы определяют и сравнивают частотность использования местоимения в анализируемых корпусах, демонстрируют специфику дискурсивного конструирования межличностного взаимодействия участников научного дискурса. Несмотря на то, что статистические тесты не показали значимых различий в частотности использования указанного местоимения, качественный анализ дискурса выявил, что в текстах корпуса научной речи русскоязычных авторов инклюзивное ше используется в дискурсивной стратегии убеждения адресата принять точку зрения автора, в то время как в подкорпусе научной речи BE2006 инклюзивные местоимения употребляются в дискурсивной стратегии репрезентации солидарности, основанной на апелляции к общим фоновым знаниям, убеждениям, ценностям и мнениям.
\end{abstract}

Ключевые слова: дискурс, академический дискурс, корпус, корпусная методология, английский язык, CQPWeb, AntConc.

Исследования финансировались Российским фондом фундаментальных исследований и правительством Волгоградской области, грант № 18-412-340007.

Научная специальность: 10.00.00 - филологические науки.

\section{Introduction}

Based within the framework of discourse theory, the study focuses on the use of the first person plural pronoun that is a means of construing interpersonal relations in academic prose by English L1 and Russian authors who uses English as a foreign language. To date, qualitative research is reinforced by corpus methodology as the advanced field that relies on statistical measures, thus providing reliability in revealing important patterns in the data. Corpus-based approach can give precise and accurate picture of how language is used across various genres, text types and registers. As genre conventions vary across countries, and texts produced in English by non-L1 speakers often incorporate linguistic features characteristic of their academic culture into foreign language writing, overuse/underuse 
features because of lack of linguistic competence or employ different discursive strategies to build relationships between participants of the communicative act that are socially and culturally marked.

Employing the corpus-based approach to compute and compare the use of linguistic features, prior studies have found that English as first language and EFL writing differs in many different ways. Research has been done on differences and similarities in the use of linking adverbials, modal verbs, conjunctions, collocations and lexical bundles (Altenberg, Granger, 2001; Martin, 2003; Gao, 2016; Yang, 2018; Siyanova \& Schmitt, 2008; Chen, 2010). Studies compare and contrast academic texts produced by nonEnglish speakers from many parts of the world and English as L1 writers.

The study of academic English papers written by authors with Russian as L1 is a relatively new field of research, and few papers have been published on the topic. Based on extensive linguistic corpus data that cover 10,000 paper titles authored by native Russian and English speakers, N. K. Ryabtseva investigates the titles of academic papers written by Russian scholars as compared to native language speakers. The study reveals cross-cultural incongruence between the corpora that arises from word-for-word translation of paper titles from Russian into English that often fails to map standard stylistic patterns characteristic to academic English. Among other reasons that account for the difference, conventions of academic genres in the two languages are mentioned. The Russian academic style uses rather extended titles with (multiple) abstract nouns, genitive constructions, etc., incorporated into a single noun group whereas the English academic style prefers a two-part title pattern, which, in its turn, employs the and-conjunction, a column, non-finite forms of the verb, prepositions, interrogative constructions, etc. (Riabtseva, 2018). In a comprehensive contrastive research of two broad classes of discourse markers, namely organisers and regulators, E. Yu. Viktorova revealed significant differences in the English and Russian academic discourse, of which the latter underuses linking elements of both types to a certain extent (Viktorova, 2015). Based on frequency of linguistic features that indicate writ- er's stances, namely the researcher, the opinion holder, and the representative, O. Krapivkina compared papers written in English and in Russian. It was found that Russian authors preferred first-person plural pronouns, the third person and agentless passives while English language writers used both first-person singular and plural, agentless constructions, third person with human reference, and personified point of view constructions (Krapivkina, 2015). Although the studies mentioned provide some quantitative data and the results seem plausible, they can hardly be validated as the authors do not employ corpus methodology.

Being spatio-spacial indicators of discourse, personal pronouns belong to the realm of interpersonal relations as they indicate participants within a communicative act, and are used for various pragmatic purposes representing communicative categories like politeness, cooperation, academic modesty, solidarity, credibility, ideological stance and social status. First person plural pronoun we admits inclusive and exclusive uses in their reference. In linguistics, clusivity is understood as semantic distinction between contextual meanings of the first person plural pronoun that influences verbal morphology. The meaning of we can be decomposed as follows: inclusive we means $I+$ you (sing.) or $I+$ you (plural), while exclusive we means $I+$ he/she; $I+$ they (Clair, 1973). Taking quantitative data as a starting point for a study, the paper seeks to reveal the underlying complex relations between language and people as they are construed in academic discourse by writers with English as L1 and English as a foreign language. Since discourse patterns are thought to be culturally determined (SalagerMeyer, 1998), interpersonal discourse strategies may differ as they are influenced by the writers' cultural background.

\section{Statement of the problem and methods}

Based on the corpus methodology to the study of 'language in use', we use a comparative research design, which is a very common scientific procedure, in which we compare two or more samples to establish whether there is a difference between them, and addresses the following research questions: 1 . Does the writing produced by 
English academic authors and Russian scholars using English for Academic Purposes contain significantly different frequencies in the use of the first person plural pronoun? 2. In what ways do English and Russian academic authors use these features differently in the context of their writing, and what do these differences reveal about interpersonal relations between discourse participants?

To conduct the study, we compiled a corpus of articles written in English by Russian language authors comprising 85 texts with the total number of words 316,716. To bring out similarities and differences with English as L1 academic writing, we chose British English 2006 corpus of written English and restricted our search to the sub-corpus of learned (academic) prose that consists of 80 texts with the total number 182,121 words (Table 1). We used the functionality of the CQPweb to extract data from the corpus (Hardie, 2012). To process the EFL corpus, we employed AntConc software tool (Lawrence, 2018). Statistical tests and visualization techniques were performed by using Lancaster statistic tools online (Brezina, 2018).

\section{Corpus structure}

The corpus of EFL academic writing consisted of articles written by Russian authors in English and published in the online editions of open access journals. The corpus included texts dealing with a wide range of scientific topics, such as engineering, natural sciences, art and humanities, social sciences, education and medicine The articles were chosen randomly and the number of texts per journal has been adjusted according to the periodical's impact.

When comparing different corpora, making informed statistical choices is an essential skill ensuring reliability (i. e. how consistently and systematically the study analyses data) and validity of a quantitative study (i. e. how closely the study reflects linguistic and social reality) (Brezina, 2018). We have to make decisions about appropriate statistical tests to perform in order to find out whether variation in occurrences is accidental or it signals a certain difference with respect to the corpora under investigation. At the next step, the data obtained from discourse were subject to statistical tests and visualized using online stat tools (Brezina, 2018) to immediately spot statistically significant differences between the groups. Qualitative analysis of the discourse data was performed with the focus on the discursive strategies spective of the findings.

\section{Discussion}

To answer research questions, normalized frequencies for the first person plural pronoun were computed for each of the corpora and for each category within the corpora. The Table 2 shows absolute and normalized frequencies of the first person plural pronoun in the corpora under investigation.

As the data demonstrate, the compared corpora do not indicate statistically significant

Table 1. Comparison of learned (academic) prose sub-corpus of BE2006 and academic prose English as a foreign language academic prose corpus

\begin{tabular}{|l|c|c|}
\hline & $\begin{array}{c}\text { Learned (aca- } \\
\text { demic) BE2006 }\end{array}$ & $\begin{array}{c}\text { English as a foreign language } \\
\text { academic prose corpus (EFL) }\end{array}$ \\
\hline The number of texts & 80 & 85 \\
\hline Average words per sample & $2,276.51$ & $3,726.07$ \\
\hline Total number of words & 182,121 & 316,716 \\
\hline
\end{tabular}

Table 2. Frequency of the first person plural pronoun we in the compared corpora

\begin{tabular}{|l|c|c|c|c|}
\hline \multirow{2}{*}{ Part-of-speech tags } & \multicolumn{2}{|c|}{ BE2006 (learned (academic) } & \multicolumn{2}{|c|}{ EFL } \\
\cline { 2 - 5 } & AF & NF & AF & NF \\
\hline Pronoun we & 402 & $2,201.83$ & 1090 & $3,170.94$ \\
\hline
\end{tabular}


differences in the use of the first person plural pronoun. To further investigate how interpersonal relationship are construed in English L1 and EFL texts, we computed normalized frequencies for the first person plural pronoun across different categories of texts and analysed contexts to spot inclusive and exclusive meanings (Table 3).

To explore the trends in the data in greater depth, Fig. 1 displays the information from the table in the form of a boxplot. The boxplot shows the distribution of a linguistic feature (the first person plural pronoun) in each category of texts (marked by circles in the graph). The box itself delineates 50 per cent of the values in the distribution, while the 'whiskers' extending from the box show the minimum and the maximum values with the exception of outliers. i. e. very distant values from the rest of the group. The long thick horizontal line shows the middle value (median), and the short horizontal line represents the mean. This form of a box plot is an informationally rich presentation of data distribution and the group tendency.

Table 3. Normalised frequencies of the first person plural pronoun we across the BE2006 and EFL corpus

\begin{tabular}{|l|c|c|c|c|c|c|}
\hline \multirow{2}{*}{\multicolumn{1}{c|}{ Type of text }} & \multicolumn{3}{|c|}{ BE2006 (academic prose) } & \multicolumn{3}{c|}{ EFL } \\
\cline { 2 - 7 } & we & Inclusive & Exclusive & we & Inclusive & Exclusive \\
\hline Art\&Humanities & 2835.75 & 252.06 & 2530.63 & 4045.06 & 925.80 & 3119.25 \\
\hline Education & 3928.57 & 2232.14 & 1696.42 & 2481.97 & 838.50 & 1626.69 \\
\hline Medicine & 2290.67 & 194.95 & 2046.03 & 5144.70 & 837.42 & 4306.73 \\
\hline Natural Sciences & 1214.08 & 73.58 & 1434.87 & 4678.18 & 641.36 & 4565.00 \\
\hline Social Sciences & 1632.33 & 165.30 & 1425.73 & 2009.58 & 490.71 & 1295.19 \\
\hline Technical & 2083.51 & 354.67 & 1640.36 & 3434.19 & 185.63 & 3434.19 \\
\hline
\end{tabular}

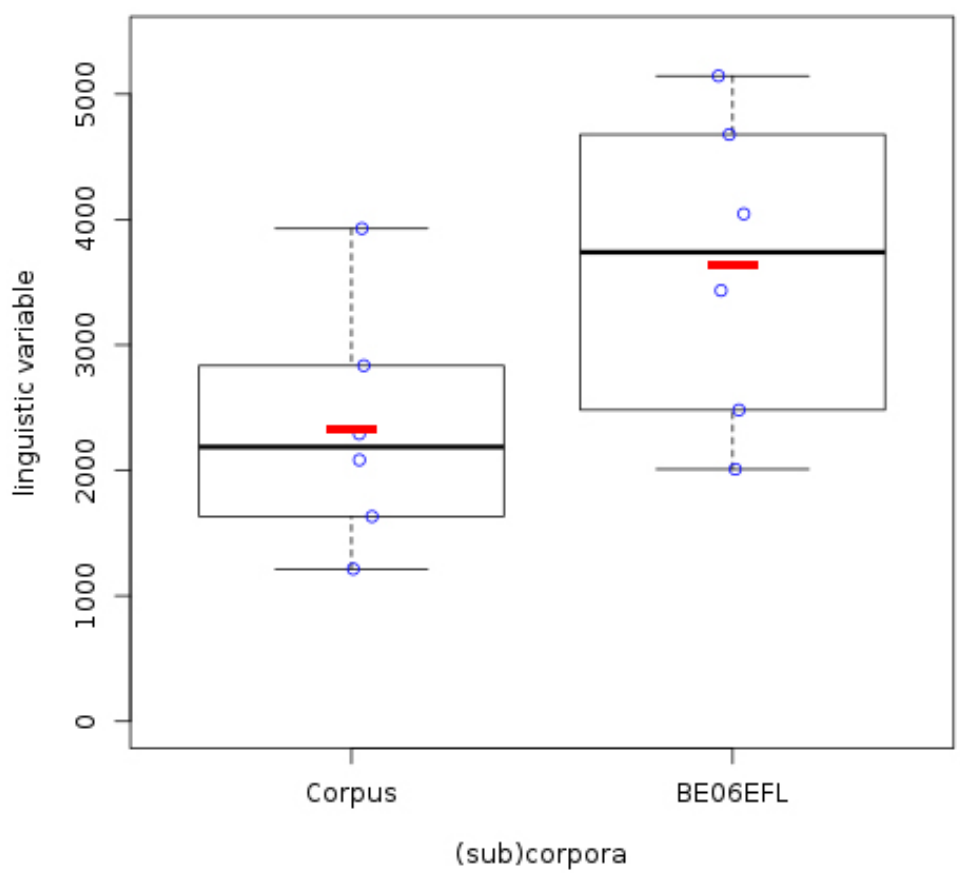

Fig. 1. The distribution of the pronoun we in BE2006 and the EFL corpus 
Further analysis was carried out to reveal differences in the use of inclusive and exclusive meanings of we across the corpora. To answer empirical question about what the data have to say about the topic of our interest, at the most basic level we need to provide an overview of the key tendencies in the data. A mean is the summary statistics of the central tendency in the data and standard deviation represents the distribution of individual values relative to the mean. The mean for inclusive use of the first person plural pronoun in the EFL corpus is 653.23, standard deviation is 278.47 . The mean for exclusive use of the first person plural pronoun is 3057.84 and standard deviation is 1351.42 . As we see, the mean is fairly good representation of the central tendency in the group because the standard deviation is small relative to the mean. In the BE2006 the mean for inclusive use of the first person plural pronoun is 583.60, standard deviation is 923.81 . The mean for exclusive use of the first person plural pronoun is 1795.67 and standard deviation is 425.17 . As we see, the mean for exclusive use of the first person plural pronoun is fairly good representation of the central tendency in the group because the standard deviation is small relative to the mean. However, in case of inclusive meaning standard deviation is much larger than the mean because of the large amount of variation between groups of texts.

Visual representation of the data can be demonstrated by using error bars plot that shows an interval within which the mean value for the group is likely to appear in 95 per cent of the samples taken from the same population. Large overlap on the error bar plot indicates that there is no statistically significant difference in the use of the first person plural pronoun between the corpora. As Fig. 2 shows, statistically significant differences in the use of inclusive and exclusive meanings of $w e$ in the EFL corpus are indicated by non-overlapping error bars. Slightly overlapping error bars, as is the case with inclusive and exclusive meanings in the BE2006 corpus, can still be statistically significant. However, no statistically significant differences are observed in the use of inclusive and exclusive meanings

\section{5\% confidence limits}

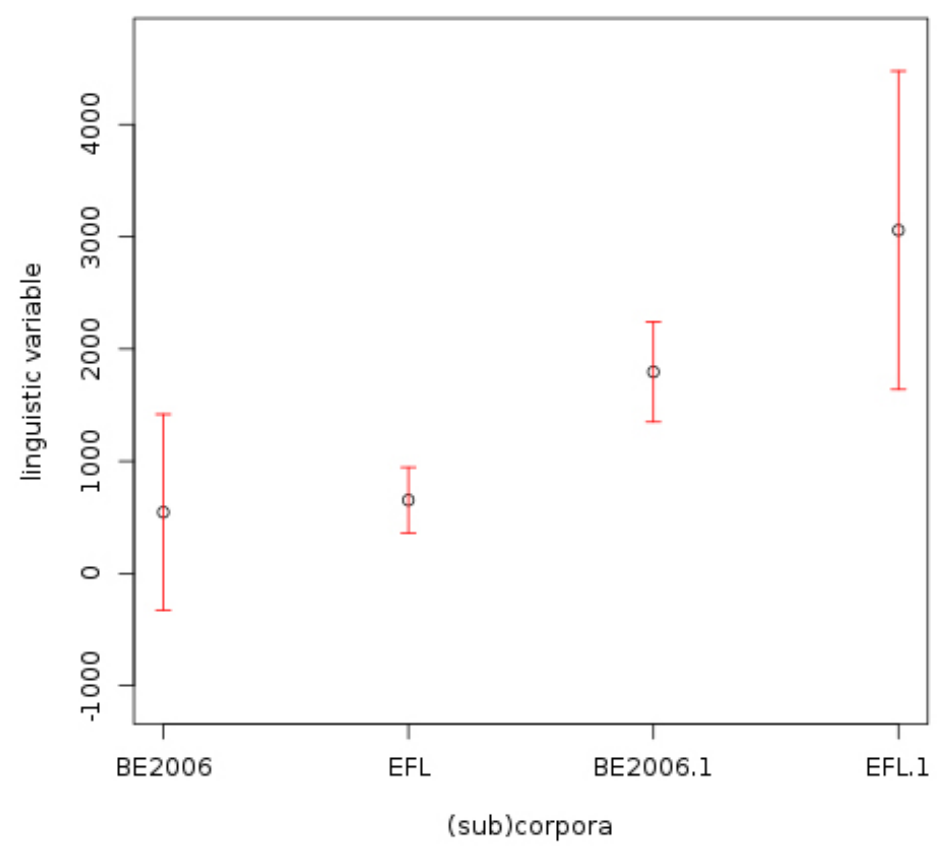

Fig. 2. Error bar plot for inclusive and exclusive first person plural pronoun in the EFL corpus and BE2006 corpus 
of the first person plural pronoun between the corpora.

Close analysis of concordances lines shows that in the EFL corpus inclusive meaning of the personal pronoun we is found in the following: (as) we can see..., we can assume..., we can/ cannot (definitely) say..., (as) we can/may observe..., (as) we observe..., we (can) find here..., we might suggest that, we can trace..., we (can) face, (as) we know/realize..., we can identify..., etc. Using the pronoun we followed by a modal verb and a lexical verb, the discursive strategy is aimed to involve the reader in the course of his arguments, thus making him an active proponent of his point of view. E.g.: As we can see from the examples, these basic national values have 'umbrella' conceptual metaphors reflecting the presidential vision of the country and its development (dual we). Comparing English and Russian folklore world views, we can identify some similarities and differences.

In the EFL corpus discursive strategy that makes use of inclusive we also refers to the addressee as a member of national community, or as a member of 'academic community', with which the author identifies themselves. E.g.: Nowadays we are facing a problem of PSA effectiveness because it becomes difficult to attract attention to the definite social problem.

Discursive strategy in the learned prose of the BE2006 corpus employs inclusive we in the similar ways (we can see, we have seen, we see), but it also tends to use inclusive meaning in general statements, communicative acts of warning, rhetorical questions, which indicate a range of pragmatic functions and serve to establish common background, appeal to common values and beliefs, introduce a topic for research, express politeness. Eg. Using the terms differently can be confusing unless we are careful; What do we know about the best balance of caring and working? Indeed, we DO know one very good reason...

Close study of concordances lines with exclusive we in the EFL corpus shows that it is observed in constructions with stative/non-action verbs, mostly mental such as we focused on the period..., we assume that there is a correlation between..., we hypothesize that..., we would like to know how our measures..., we expect our re- sults to reflect..., we consider the following linear regression model..., we think over a question..., etc.) and relational (we deal with, we rely upon, we need, ..., etc.) predicates.

Exclusive we is used in predicative constructions with 'action/dynamic' verbs describing the actions taken by researcher/researchers to obtain the results presented in the paper: we coded commissioned ranks as they appear on..., we included 8 lexemes recorded in 71 cases of us..., we introduced additional grades for lower ranks..., we calculated the mass and volume of basalt..., we studied the process of catalytic hydrogenolysis..., we used the nanoscale $R u$ and Ni metallic..., we obtained much more accurate results..., we applied the fast algorithm for computing..., we replaced $G$ by an isogenous group..., we collected this species in two localities in..., we presented the data from the first description, etc.

With respect to the use of exclusive we, the compared corpora show much less difference, as BE2006 corpus contains contexts with mental predicates such as believe, think, assume, consider, expect, concentrate etc. and action/dynamic verbs such as construct, include, compare, undertake, adopt, etc. These are employed to state agency through describing stages of research in a report-like style that suggests objectivity and construes credibility in discourse.

\section{Conclusion}

Empirical analysis revealed that English L1 and Russian language writing do not show statistically significant differences in the frequency of the first person plural pronoun that is used in discursive strategies to construe interpersonal relations between the participants of a communicative act in academic writing. Statistical tests as well as visual techniques prove that the compared groups of texts are homogeneous as the means indicate central tendency fairly well. However, it was found that with respect to inclusive and exclusive meanings of the pronoun statistically significant differences are observed both in the EFL corpus and BE2006 corpus.

In pragmatic perspective, inclusive meaning represents communicative categories that are likely to be culturally determined. In the BE2006 corpus, discursive strategies with inclusive we 
perform a much wider range of pragmatic functions than in the EFL corpus, as they are used to construe the interpersonal relations of solidarity based on common background knowledge, shared beliefs and opinions, whereas in the EFL corpus discursive strategies employ inclusive we to persuade the addressee to share and accept the author's arguments. Both corpora employ action/dynamic verbs and mental predicates in a report style manner to support arguments and build academic credibility.
The results of research may be useful in teaching academic discourse as it is important to be aware of different pragmatic functions of linguistic means used to verbalize discursive strategies in academic writing. Differences observed in the use of the first person plural pronoun across English and Russian might be also helpful to Russian students and researchers as they need to know the conventions which are favored in EL academic writing.

\section{References}

Altenberg, B., Granger, S. (2001). The grammatical and lexical patterning of MAKE in native and non-native student writing. In Applied Linguistics, 22, 173-194.

Anthony, L. (2018). AntConc (Version 3.5.7) [Computer Software]. Tokyo, Japan: Waseda University. Available at: http://www.laurenceanthony.net/software (accessed 5 July 2018).

Chen, Ya.-H, Baker, P. (2010). Lexical Bundles in L1 and L2 Academic Writing. In Language Learning and Technology, 14 (2), 30-49.

Gao, X. (2016). A cross-disciplinary corpus-based study on English and Chinese native speaker' use of linking adverbials in academic writing. In Journal of English for Academic Purposes, 24, 14-28.

Hardie, A. (2012). CQPweb - combining power, flexibility and usability in a corpus analysis tool. In International Journal of Corpus Linguistics, 17 (3), 380-409.

Krapivkina, O. (2015). Verbalization of the Writer in Academic Prose. In The Journal of Siberian Federal University (Humanities and Social Sciences), 8, 1625-1674.

Martin, P.M. (2003). A Genre Analysis of English and Spanish Research Paper Abstracts in Experimental Social Sciences. In English for Specific Purposes, 1, 25-43.

Riabtseva, N.K. (2018). Academic Papers Titles and their dominating patterns: a Russian - English Perspective. In Science Journal of VolSU. Linguistics, 17, 2, 6, 33-43. DOI: https://doi.org/10.15688/jvolsu2.2018.2.4

Salager-Meyer, F. (1998). Language is not a Physical Object. In English for Specific Purposes, 17 (3), 295-302.

Siyanova, A., Schmitt, N. (2008). The Canadian Modern Language Review. In La Revue canadienne des langues vivantes, 64 (3), 429-458

Yang, X. (2018). A corpus-based Study of Modal Verbs in Chinese Learners' Academic Writing. In English Language Teaching, 11 (2), 122-130.

Viktorova, E. Yu. (2015). Vspomogatel'naya systema diskursa [Supportive system of discourse]. Saratov: Izdatel'skiy tsentr Nauka, $404 \mathrm{p}$.

Wenlong, W., Ling, Zh., Zhen, L., Wenxian, X. (2011). A Corpus-Based Study with Corpus Materials on Conjunctions Used by Chinese and English Authors in English Academic Article Abstracts. In Advances in Computer Science, Intelligent Systems and Environment,104, 589-593 